\title{
Temporal variations in the primary productivity of Eleocharis acutangula (Cyperaceae) in a tropical wetland environment
}

\author{
GUSTAVO GOMES CHAGAS ${ }^{1,2}$, GISELLI MARTINS DE ALMEIDA FREESZ ${ }^{1}$ and \\ MARINA SATIKA SUZUKI ${ }^{1}$
}

(received: Apr 15, 2009; accepted: June 20, 2012)

\begin{abstract}
Temporal variations in the primary productivity of Eleocharis acutangula (Cyperaceae) in a tropical wetland environment). Wetland vegetation typically includes aquatic macrophytes with high primary production capacities. The present study investigated how hydrological variations affect biomass allocation and primary productivity in the emergent macrophyte Eleocharis acutangula (Roxb.) Schult. Eleocharis acutangula ramets were collected from the Campelo Lagoon flood plain ( $21^{\circ} 39^{\prime} \mathrm{S}, 41^{\circ} 12^{\prime} \mathrm{W}$ and $21^{\circ} 37 \mathrm{~S}, 41^{\circ} 11^{\prime} \mathrm{W}$ ) between March/2005 and February/2006. This region experienced an unusually short rainy period between November/2005 and February/2006 that generated atypically high primary production levels $\left(128 \mathrm{gDW} \mathrm{m}^{-2}\right.$ month $\left.^{-1}\right)$ and total biomass gains $\left(447 \mathrm{gDW} \mathrm{m}^{-2}\right)$ in May and June/2005 respectively. Our data indicated that primary production and biomass allocation were strongly influenced by variations in wetland water levels and that macrophytes quickly invested in biomass accumulation when surface water levels rised.
\end{abstract}

Key words - aquatic macrophyte, biomass allocation, primary production, wetland

\section{INTRODUCTION}

Wetlands are transition regions between terrestrial and aquatic environments where the water table is very close to the surface or the soil is actually covered by standing water, and they are considered the most productive ecosystems on the planet (Mitsch \& Grosselink 2007). Wetland vegetation typically consists of aquatic macrophytes with high primary productivity capacities (Esteves 1998).

Hydrological conditions are of upmost importance in maintaining the structure and functioning of wetlands, affecting nutrient availability, soil anaerobiosis and salinity, and determining species composition and richness (Amezaga et al. 2002). When hydrological patterns remain regular, the ecological integrity of these ecosystems can persist unchanged for many years (Mitsch \& Gosselink 2007).

Seasonal variations in primary productivity and in the organic and inorganic compositions of aquatic macrophytes are very apparent in temperate regions (Fernández-Alaez et al. 2002, Fox et al. 2008). These variations are not always as evident in tropical regions

\footnotetext{
1. Universidade Estadual do Norte Fluminense Darcy Ribeiro, Centro de Biociências e Biotecnologia, Laboratório de Ciências Ambientais, Av. Alberto Lamego, 2000, Pq. Califórnia, 28013-600 Campos dos Goytacazes, RJ, Brazil.

2. Corresponding author: chagas.gg@gmail.com
}

(Esteves et al. 2005, Freesz 2007), although it is possible to detect seasonal changes in the chemical compositions and biomasses of aquatic macrophytes in environments that experience marked variations in their water levels (Da Silva \& Esteves 1993, Santos \& Esteves 2002). The primary production rates of aquatic macrophytes in tropical environments are known to be sensitive to variations in temperature and light levels, as well as to water and nutrient availability (Neue et al. 1997).

The present study evaluated primary productivity and biomass allocation in the emergent macrophyte Eleocharis acutangula (Roxb.) Schult. in northern Rio de Janeiro State, a region with numerous lentic environment that experience both periodic flooding and drought conditions.

\section{MATERIAL AND METHODS}

This study was carried out in a wetland ecosystem in the municipality of Campos dos Goytacazes in northern Rio de Janeiro State, Brazil. This wetland site is part of the seasonally flooded area of the Campelo Lagoon (21⒊' S, $41^{\circ} 12^{\prime} \mathrm{W}$ and $\left.21^{\circ} 37 \mathrm{~S}, 41^{\circ} 11^{\prime} \mathrm{W}\right)$. The site is narrow and elongated, and parallel to a lagoon that overflows and floods it during the rainy season.

This site may accumulate up to $80 \mathrm{~cm}$ of water during the rainy period (October-March), although it will fully drain during the dry period (June-September), leaving only 
boggy soils. The area is colonized by permanent stands of Typha domingensis Pers. and seasonal stands of Nymphaea sp., Eleocharis acutangula, and Chara sp. The region has a tropical dry to sub-humid climate (Fiderj 1978) with a total annual rainfall of approximately $1000 \mathrm{~mm}$ that is fairly well-distributed heat throughout the year, but with higher precipitation rates during the austral summer and dry winters. Average temperatures remain between 20 and $30^{\circ} \mathrm{C}$.

Eleocharis acutangula was sampled on a monthly basis from March/2005 to February/2006. Ten $0.25 \mathrm{~m}^{2}$ plots were established along a 50 meter transect at intervals of 5 meters, and all of the macrophytes present inside the plots were cut at sediment level and placed in plastic bags. The water levels in the wetland areas were measured when the macrophytes were harvested. The samples were washed in running water in the laboratory and separated into chlorophyllous portions (ramets with more than $50 \%$ of their length having chlorophyllous tissue) and debris (less than $50 \%$ of the ramet length containing chlorophyllous tissue). The samples were dried at $70{ }^{\circ} \mathrm{C}$ to a constant weight, and the biomass expressed as average dry weight per square meter $\left(\mathrm{gDW} \mathrm{m}^{-2}\right)$.

The primary aerial production (PAP) was determined according to Smalley (1959). Positive changes in living biomass between two consecutive samplings periods were noted and biomass losses during the time intervals were considered to consist of debris biomass.

$$
\begin{aligned}
& \mathrm{PAP}=\Delta \mathrm{V}+\Delta \mathrm{S} \text { when } \Delta \mathrm{S}>0 \text { and } \Delta \mathrm{V}>0 \\
& \mathrm{PAP}=0 \text { when } \Delta \mathrm{S}<0 \text { and } \Delta \mathrm{V}<0 \\
& \mathrm{PAP}=\Delta \mathrm{S} \text { when } \Delta \mathrm{S}>0 \text { and } \Delta \mathrm{V}<0 \\
& \mathrm{PAP}=\Delta \mathrm{V} \text { when } \Delta \mathrm{S}<0 \text { and } \Delta \mathrm{V}>0 \\
& \text { Where: } \\
& \Delta \mathrm{V}=\text { variation in Chlorophyll Biomass } \\
& \Delta \mathrm{S}=\text { variation in Debris Biomass }
\end{aligned}
$$

Spearman's coefficient $(P=0.05)$ was used to evaluate the degrees of correlation between the variables.

\section{RESULTS}

Reductions in the total aerial biomass of the macrophyte were observed to follow reductions in water levels in the wetland site. The highest biomass values were observed between April and July, as well as in September, when they exceeded $400 \mathrm{gDW} \mathrm{m}^{-2}$ (figure 1A). A small increase in total biomass was observed between April and September/2005, with lower water depths, despite reductions in chlorophyllous biomasses and increases in debris biomass. The correlation between chlorophyllous biomass and water level was highly significant (Spearman $P>0.0001$ ).
The total aboveground biomass of E. acutangula varied from $21 \mathrm{gDW} \mathrm{m}^{-2}$ (February 2006) to $447 \mathrm{gDW} \mathrm{m}^{-2}$ (July 2005). The highest chlorophyllous biomass value (which varied between 13.6 and $305 \mathrm{gDW} \mathrm{m}^{-2}$ ) was observed in April 2005 (figure 1B) at the end of the rainy period. The maximum senescent biomass was observed in September 2005 (291 gDW m $\mathrm{gD}^{-2}$.

Primary aerial production increased only in April, May and July/2005, when the wetland water levels were above $50 \mathrm{~cm}$ (figure 1C). The highest PAP value was observed in May/2005 (128 gDW m² month $\left.^{-1}\right)$ and the lowest positive value was observed in April/2005 $\left(45 \mathrm{gDW} \mathrm{m}^{-2}\right.$ month $\left.^{-1}\right)$. Primary production values were zero or negative between August/2005 and February/2006, although the method does not account for these values. The annual primary production was estimated at $282 \mathrm{gDW} \mathrm{m}^{-2}$ year ${ }^{-1}$.
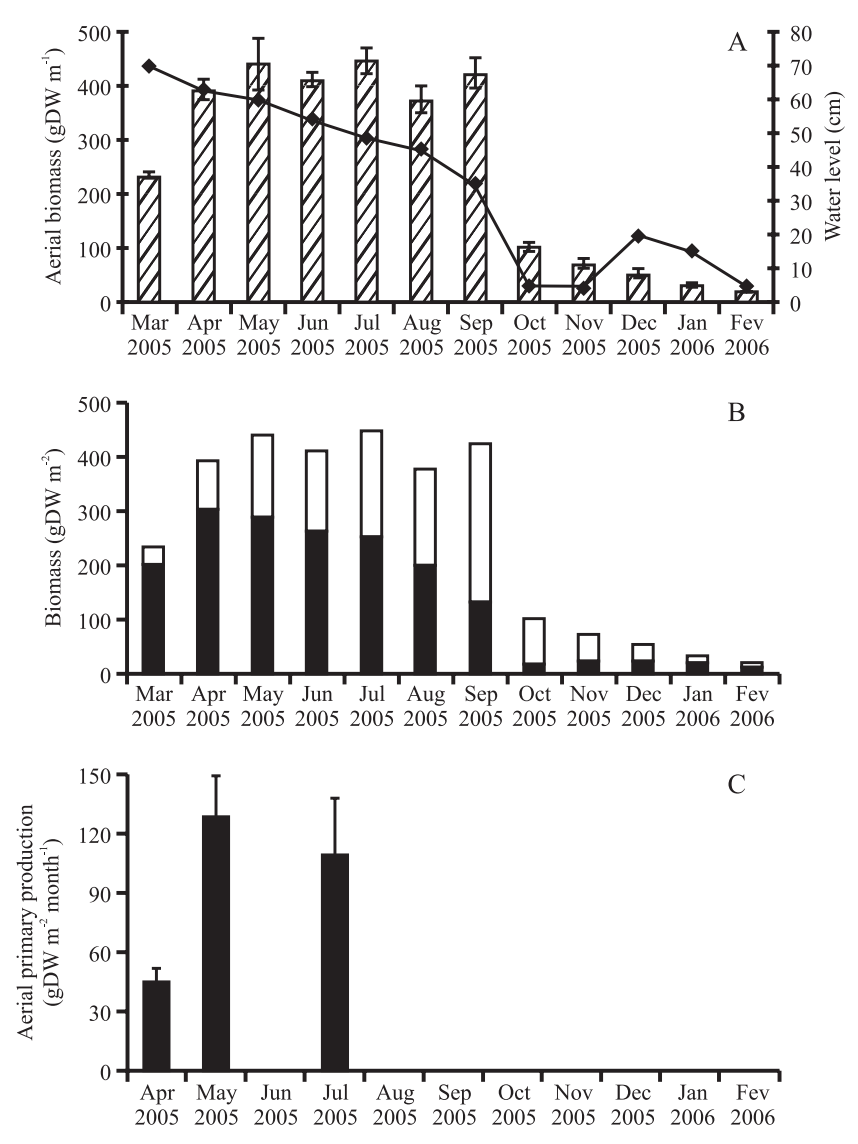

Figure 1. Temporal variations of aerial biomass and water levels (A), chlorophyllous biomass and debris biomass (B), and aerial primary production $(\mathrm{C})$ of the aquatic macrophyte Eleocharis acutangula growing in a wetland area in the municipality of Campos dos Goytacazes in northern Rio de Janeiro State, Brazil, between March/2005 and February/2006. Averages of 10 samples from $0.25 \mathrm{~m}^{2}$ plots. Error bars indicate standard deviations. 


\section{DISCUSSION}

The hydrochemistry and dynamics of wetland environments are strongly affected by annual variations in rainfall (Mitsch \& Gosselink 2007). The leaves of aquatic macrophytes sprout throughout the year in tropical environments, although there is evidence that waterlevel fluctuations induce changes in aquatic macrophyte productivity and biometry (Froend \& McComb 1994, Penha et al. 1999, Santos \& Esteves 2004). The results of the present work corroborate those of previous studies indicating that variations in Eleocharis acutangula aerial biomass are strongly associated with variations in wetland water levels (figure 1A).

The variation seen in chlorophyllous biomass follow the developmental dynamics of E. acutangula ramets in these wetlands (figure 1B). Despite the fact that primary aerial production values decreased with receding water levels in March, they were higher in April and May/2005. Increases in the proportion of chlorophyllous biomass to total biomass were observed in December/ 2005 following a slight increase in wetland water levels (figure 1A), clearly indicating that these plants invest in growth, biomass allocation, and ramet development in response to variations in wetland water levels, with increasing water levels resulting in increases in the total aerial biomass and chlorophyllous biomass.

The populations of E. acutangula demonstrated increasing senescence as water levels decreased, and these plants will even disappear when the sediments become fully exposed. Variations in the wetland water levels cause differential disturbances in the different macrophyte populations in the ecosystem, but even the complete exposition of the sediment surface does not result in the total elimination of the aerial biomass of Typha domingensis, for example. Previous studies of T. domingensis showed that this macrophyte can grow in saturated soils without any standing water (Esteves \& Suzuki 2008).

The present study determined that the period of aquatic macrophyte growth in tropical wetlands is related to increases in standing water levels, and not to seasonal temperature variations, as has been reported by other authors (Thomaz \& Bini 1998, Pezzato \& Camargo 2004).

The biomass data obtained in the present study was similar to that reported in other studies: Santos \& Esteves (2004) noted that the total biomass values of Eleocharis interstincta (Vahl) Roemer varied from $20 \mathrm{gDW} \mathrm{m}^{-2}$ to $339 \mathrm{gDW} \mathrm{m}^{-2}$ in the Jurubatiba coastal lagoon; Enrich-Prast et al. (2002) reported that the total biomass values of Oryza glumaepatula Steud. varied from $7.1 \mathrm{gDW} \mathrm{m}^{-2}$ to $467 \mathrm{gDW} \mathrm{m}^{-2}$ in a non-impacted area of Lake Batata in the Amazon Region. Interestingly, the highest biomass values in the present study were observed during an atypical dry period, while these other studies reported maximum biomass values during the rainy period when water levels increase.

The annual PAP value observed for E. acutangula in the present study $\left(282 \mathrm{gDW} \mathrm{m}^{-2}\right.$ year-1 $\left.^{-1}\right)$ was lower than that observed for Eleocharis interstincta by Santos \& Esteves (2002) in the Jurubatiba coastal lagoon $\left(\mathrm{PAP}=1012 \mathrm{gDW} \mathrm{m}^{-2}\right.$ year $\left.^{-1}\right)$, which may be related to low productivity during the $2005 / 2006$ rainy period and clearly indicates that hydrological variations are the most important factors influencing the dynamics of Eleocharis acutangula productivity.

In conclusion, reductions in wetland water levels produced extensive mortality of Eleocharis acutangula populations, and our data indicates that hydrological variations are an important factor in the dynamics of aquatic macrophyte growth in tropical wetlands.

Acknowledgements - The authors thank the Environmental Sciences Lab/UENF for the use of their facilities and for logistical support; Faperj for providing research funding; and UENF/Capes for their support through the Masters scholarship program.

\section{REFERENCES}

Amezaga JM, Santamaría L, Green AJ. 2002. Biotic wetland connectivity-supporting a new approach for wetland policy. Acta Oecologica 23:213-222.

Da Silva CJ, Esteves FA. 1993. Biomass of three macrophytes in the pantanal of the Mato Grosso. Brazilian International Journal Ecology and Environmental 19:11-22.

Enrich-Prast A, Esteves FA, Breves AR. 2002. Variation of biometric parameters and $\mathrm{C}, \mathrm{N}$ and $\mathrm{P}$ concentrations of Oryza glumaepatula at diferent depths of an Amazonian lake impacted by bauxite tailings (Lake Batata, Pará, Brazil). Brazilian Journal of Biology 62:85-92.

Esteves FA. 1998. Fundamentos de limnologia. 2 ed., Interciência, Rio de Janeiro.

Esteves BS, Suzuki MS. 2008. Typha domingensis Pers. subject to interactions among water level and fire event in a tropical lagoon. Acta Limnologica Brasiliensia 20:227-234.

Esteves BS, Taouil A, Suzuki MS. 2005. Nutrient composition of macroalgae and macrophytes of the Açu lagoon, Rio de Janeiro State, Brazil. Acta Limnologica Brasiliensia 17:233-244.

Fernández-Alaez M, Fernández-Alaez C, Rodríguez S. 2002. Seasonal changes in biomass of charophytes in shallow lakes in the northwest of Spain. Aquatic Botany 72: 335-348. 
Fiderj - Fundação Instituto de Desenvolvimento Econômico e Social do Rio de Janeiro. 1978. Indicadores climatológicos do estado do Rio de Janeiro. Série SIPE - Sistemas de Informação para o Planejamento Estadual, Rio de Janeiro.

Fox SE, Stieve E, Valiela I, Hauxwell J, McClelland J. 2008. Macrophyte abundance in Waquoit Bay: effects of land-derived nitrogen loads on seasonal and multiyear biomass patterns. Estuaries and Coasts 31: 532-541.

Freesz GMA. 2007. Produção de biomassa e decomposição de folhas de Typha domingensis Pers. na Lagoa do Campelo, RJ. Dissertação de mestrado, Universidade Estadual do Norte Fluminense Darcy Ribeiro, Campos dos Goytacazes, Rio de Janeiro.

Froend RH, McComb AJ. 1994. Distribution, productivity and reproductive phenology of emergent macrophytes in relation to water regimes at wetlands of south-western Australia. Austalian Journal Marine Freshwater Research 45:1491-1508.

Mitsch WJ, Gosselink JG. 2007. Wetlands. John Wiley \& Sons, New York.

Neue HU, Gaunt JL, Wang ZP, Becker-Heidmann P, Quijano C. 1997. Carbon in tropical wetlands. Geoderma 79: 163-185.
Penha JMF, Da Silva CJ, Bianchini Júnior I. 1999. Productivity of the aquatic macrophyte Pontederia lanceolata Nvtt. (Pontederiaceae) on floodplains of the Pantanal Mato-grossense, Brazil. Wetlands Ecology and Management 7:155-163.

Pezzato MM, Camargo AFM. 2004. Primary production of the aquatic macrophyte, Egeria densa Planch. (Hydrocharitaceae) in two rivers from the Itanhaém River basin in São Paulo State, Brazil. Brazilian Archives of Biology and Technology 47:153-162.

Santos AM, Esteves FA. 2002. Primary production and mortality of Eleocharis interstincta in response to water level fluctuations. Aquatic Botany 74:189-199.

Santos AM, Esteves FA. 2004. Influence of water level fluctuation on the mortality and aboveground biomass of the aquatic macrophyte Eleocharis interstincta (Vahl) Roemer et Schults. Brazilian Archives of Biology and Technology 47:281-290.

Smalley AE. 1959. The role of two invertebrate populations, Littorina irrorata and Orchelimum fidicinium, in the energy flow of salt marsh ecosystem. Dissertation, University of Georgia, Georgia.

Thomaz SM, Bini LM. 1998. Ecologia e manejo de macrófitas aquáticas em reservatórios. Acta Limnologica Brasiliensia 10:103-116. 